\title{
Identifying HotSpots in Lung Cancer Data Using Association Rule Mining
}

\author{
Ankit Agrawal and Alok Choudhary \\ Dept. of Electrical Engg. and Computer Science \\ Northwestern University \\ 2145 Sheridan Rd, Evanston, IL 60201, USA \\ Email: \{ankitag,choudhar\}@eecs.northwestern.edu
}

\begin{abstract}
We analyze the lung cancer data available from the SEER program with the aim of identifying hotspots using association rule mining techniques. A subset of 13 patient attributes from the SEER data were recently linked with the survival outcome using prediction models, which is used in this study for segmentation. The goal here is to identify characteristics of patient segments where average survival is significantly higher/lower than average survival across the entire dataset. Automated association rule mining techniques resulted in hundreds of rules, from which many redundant rules were manually removed based on domain knowledge. The resulting rules conform with existing biomedical knowledge and provide interesting insights into lung cancer survival.
\end{abstract}

Keywords-Association rule mining; hotspots; lung cancer;

\section{INTRODUCTION}

Lung cancer ranks second in the list of most common cancers [1], and first in the list of most deadly cancers [2], with the survival rate being about $15 \%$ after 5 years of diagnosis [3].

The Surveillance, Epidemiology, and End Results (SEER) Program [4] of the National Cancer Institute is an authoritative repository of cancer statistics in the United States [5]. It is a population-based cancer registry which covers about $26 \%$ of the US population across several geographic regions and is the largest publicly available domestic cancer dataset. The data includes patient demographics, cancer type and site, stage, first course of treatment, and follow-up vital status. The SEER program collects cancer data for all invasive and in situ cancers, except basal and squamous cell carcinomas of the skin and in situ carcinomas of the uterine cervix [3]. The 'SEER limited-use data' is available from the SEER website on submitting a SEER limiteduse data agreement form. [6] presents an overview study of the cancer data at all sites combined and on selected, frequently occurring cancers from the SEER data. The SEER data attributes can be broadly classified as demographic attributes (e.g. age, gender, location), diagnosis attributes (e.g. primary site, histology, grade, tumor size), treatment attributes (e.g. surgical procedure, radiation therapy), and outcome attributes (e.g. survival time, cause of death), which makes the SEER data ideal for performing outcome analysis studies.
Recently, lung cancer data from SEER was used to construct predictive models for lung cancer survival after 6 months, 9 months, 1 year, 2 years, and 5 years of diagnosis using several machine techniques [7]. In this work, we use same dataset with 13 predictor attributes as used for the lung cancer outcome calculator in [7] for association rule mining analysis.

The rest of the paper is organized as follows: Section II gives an overview of association rule mining and describes the HotSpot algorithm used in this work, followed by a description of the data and its attributes in Section III. Experiments and results are presented in Section IV, and finally the conclusion and future work in Section V.

\section{Association Rule Mining}

Association rule mining is often stated as follows [8]: Let $I$ be a set of $n$ binary attributes called items. Let $T$ be a set of transactions. Each transaction in $T$ contains a subset of the items in $I$. A rule is defined as an implication of the form $X \Rightarrow Y$ where $X, Y \subseteq I$ and $X \cap Y=\phi$. The sets of items $X$ and $Y$ are called antecedent (left-hand-side or LHS) and consequent (right-hand-side or RHS) of the rule respectively. A commonly given example from market basket analysis is of the rule $\{$ Bread $\} \Rightarrow\{$ Butter $\}$, meaning that customers who buy bread also buy butter.

Association rule mining is popularly done with flag attributes, indicating the presence/absence of the item in the transaction. However, even from nominal attributes (having multiple but finite possible values), and numeric attributes, it is possible to derive flag attributes for the purpose of association rule mining.

\section{HotSpot Algorithm}

This is an association rule mining algorithm which is directed by a target attribute, which means that the RHS or consequent is fixed to the target attribute. It can be used for segmentation with both nominal and numeric targets, where the LHS or antecedent would define the segment characteristics for segments which are significantly different from the entire dataset in terms of the target attribute. For example, if the target is a numeric attribute like the patient survival time, and the average patient survival time is $t_{a v g}$, 
then it would be interesting to find segments in the data where the average patient survival time is higher/lower than $t_{\text {avg. }}$ Similarly, if the target is a nominal attribute like 5year-survival (whether or not a patient survived for at least 5 years), and the fraction of survived patients in the entire dataset is $f$, then it would be interesting to find segments where this fraction is higher/lower than $f$.

It uses a greedy approach to construct the tree of rules in a depth-first fashion, where the search is constrained by the following parameters:

1) Maximum branching factor: The number of children nodes to consider at each node. This parameter controls the amount of search performed, since the algorithm uses a greedy search.

2) Minimum improvement in target value: This is the minimum improvement in the target value of the resulting segment in order to consider adding a new branch.

3) Minimum segment size: The size of the resulting segment must be at least this much in order to add a new branch.

The HotSpot algorithm then, is straightforward. It begins with the entire dataset at the top, and goes down the data in a depth-first fashion using a greedy approach, i.e., it branches on that attribute which gives the maximum improvement in target value subject to the above constraints, and recursively tries the same at every node. Each node represents a segment, and hence, an association rule.

The improvement in the target value can be defined as either an increase or a decrease in the average target value (in case of numeric targets) or target fraction (in case of nominal targets).

We use the implementation of the HotSpot algorithm provided in the WEKA data mining toolkit [9].

\section{Lung CANCER DATA For Association Rule MINING}

The lung cancer outcome calculator [7] mentioned earlier uses the data from the SEER November 2008 Limited-Use Data files [4] (released in April 2009) from nine SEER registries (Atlanta, Connecticut, Detroit, Hawaii, Iowa, New Mexico, San Francisco-Oakland, Seattle-Puget Sound, and Utah). This data had a follow-up cutoff date of December 31,2006 , i.e., the patients were diagnosed and followed-up upto this date. Subsequently, the data was selected for the patients diagnosed between 1998 and 2001, due to various reasons mentioned in [7], the primary being that it allowed predictive modeling of survival of upto 5-years (since the follow-up cutoff date was December 31, 2006, data used was for cancer patients with year of diagnosis as 2001 or before). The lung cancer outcome calculator uses the following 13 patient attributes:

1) Age at diagnosis: Numeric age of the patient at the time of diagnosis for lung cancer.
2) Birth place: The place of birth of the patient.

3) Cancer grade: A descriptor of how the cancer cells appear and how fast they may grow and spread.

4) Diagnostic confirmation: The best method used to confirm the presence of lung cancer.

5) Farthest extension of tumor: The farthest documented extension of tumor away from the lung, either by contiguous extension (regional growth) or distant metastases (cancer spreading to other organs far from primary site through bloodstream or lymphatic system).

6) Lymph node involvement: The highest specific lymph node chain that is involved by the tumor. Cancer cells can spread to lymph nodes near the lung, which are part of the lymphatic system (the system that produces, stores, and carries the infection-fightingcells. This can often lead to metastases.

7) Type of surgery performed: The surgical procedure that removes and/or destroys cancerous tissue of the lung, performed as part of the initial work-up or first course of therapy.

8) Reason for no surgery: The reason why surgery was not performed (if not).

9) Order of surgery and radiation therapy: The order in which surgery and radiation therapies were administered for those patients who had both surgery and radiation.

10) Scope of regional lymph node surgery: It describes the removal, biopsy, or aspiration of regional lymph node(s) at the time of surgery of the primary site or during a separate surgical event.

11) Cancer stage: A descriptor of the extent the cancer has spread, taking into account the size of the tumor, depth of penetration, metastasis, etc.

12) Number of malignant tumors in the past: An integer denoting the number of malignant tumors in the patient's lifetime so far.

13) Total regional lymph nodes examined: An integer denoting the total number of regional lymph nodes that were removed and examined by the pathologist.

Table I presents the attributes of the lung cancer dataset, and Tables II-X present the possible values and codes of all the nominal attributes, except birth place, since there are too many possible values for birth place.

For association rule mining analysis, we removed all missing/unknown values, since we are interested in finding segments with precise definitions in terms of patient attributes. The survival time (in months) was chosen as the target attribute for the HotSpot algorithm. The dataset had 13,033 instances, 13 input patient attributes, and 1 target attribute. The average survival time in the entire dataset was 24.45 months. So, we would be interested to find segments of patients where the average survival time is significantly 
Table I

Lung CAncer Dataset ATtributes

\begin{tabular}{||l|l||}
\hline \hline Attribute & Type \\
\hline \hline Age at diagnosis & Numeric \\
\hline Birth place & Nominal \\
\hline Cancer grade & Nominal \\
\hline Diagnostic confirmation & Nominal \\
\hline Farthest extension of tumor & Nominal \\
\hline Lymph node involvement & Nominal \\
\hline Type of surgery performed & Nominal \\
\hline Reason for no surgery & Nominal \\
\hline Order of surgery and radiation therapy & Nominal \\
\hline Scope of regional lymph node surgery & Nominal \\
\hline Cancer stage & Nominal \\
\hline Number of malignant tumors in the past & Numeric \\
\hline Total regional lymph nodes examined & Numeric \\
\hline Survival time & Numeric \\
\hline \hline
\end{tabular}

Table II

CODES For CANCER GRAdE

\begin{tabular}{||c|l||}
\hline \hline Code & Description \\
\hline \hline 1 & Grade I (well-differentiated) \\
\hline 2 & Grade II (moderately differentiated) \\
\hline 3 & Grade III (poorly differentiated) \\
\hline 4 & Grade IV (undifferentiated) \\
\hline 9 & Not determined/not stated/NA \\
\hline \hline
\end{tabular}

Table III

CODES For DiAgnostic CONFIRMATION

\begin{tabular}{||c|l||}
\hline \hline Code & Description \\
\hline \hline 1 & Positive histology \\
\hline 2 & Positive cytology \\
\hline 4 & Positive microscopic confirmation (method unspecified) \\
\hline 5 & Positive laboratory test/marker study \\
\hline 6 & Direct visualization without microscopic confirmation \\
\hline 7 & $\begin{array}{l}\text { Radiology and other imaging techniques without microscopic } \\
\text { confirmation }\end{array}$ \\
\hline 8 & Clinical diagnosis only (other than above) \\
\hline 9 & Unknown whether microscopically confirmed \\
\hline \hline
\end{tabular}

Table IV

CODES FOR TUMOR EXTENSION

\begin{tabular}{||c|l||}
\hline \hline Code & Description \\
\hline \hline 0 & In situ (Noninvasive/intraepithelial) \\
\hline 10 & Tumor confined to one lung (excl. primary in MSB) \\
\hline 20 & Main stem bronchus $>2.0 \mathrm{~cm}$ from carina \\
\hline 25 & Primary confined to carina \\
\hline 30 & Localized (NOS) \\
\hline 40 & Pleura/Visceral/Pulmonary ligament without pleural effusion \\
\hline 50 & Main stem bronchus $<2.0 \mathrm{~cm}$ from carina \\
\hline 60 & Chest (thoriac) wall/Diaphragm \\
\hline 65 & Separate tumor nodule(s) in the same lobe \\
\hline 70 & Carina/Trachea/Esophagus \\
\hline 71 & Heart/Visceral pericardium \\
\hline 72 & Pleural effusion \\
\hline 73 & Adjacent rib \\
\hline 75 & Sternum/Vertebra(e)/Skeletal muscle/Skin of chest \\
\hline 77 & Separate tumor nodule(s) in different lobe \\
\hline 78 & Separate tumor nodule(s) in contralateral lung \\
\hline 79 & Pericardial effusion \\
\hline 80 & Further contiguous extension \\
\hline 85 & Metastatis \\
\hline 99 & Unknown if extension or metastatis \\
\hline \hline
\end{tabular}

Table V

CODES FOR LYMPH NODE INVOLVEMENT

\begin{tabular}{||c|l||}
\hline \hline Code & Description \\
\hline \hline 0 & No lymph node involvement \\
\hline 1 & Intrapulmonary/Hilar/Peribronchial \\
\hline 2 & $\begin{array}{l}\text { Subcarinal/Carinal/Mediastinal/ Tracheal/Aortic/Pulmonary liga- } \\
\text { ment/Pericardial }\end{array}$ \\
\hline 5 & Regional lymph node(s) \\
\hline 6 & $\begin{array}{l}\text { Contralateral hilar/Supraclavicular/ Ipsilateral/Contralateral/ } \\
\text { Scale }\end{array}$ \\
\hline 7 & Other than above (incl. cervical neck nodes) \\
\hline 8 & Distant lymph nodes (NOS) \\
\hline 9 & Unknown/Not stated \\
\hline \hline
\end{tabular}

Table VI

CODES FOR TYPE OF SURGERY

\begin{tabular}{||c|l||}
\hline \hline Code & Description \\
\hline \hline 0 & No surgery \\
\hline 12 & Laser ablation/cryosurgery \\
\hline 13 & Electrocautery/Fulguration \\
\hline 15 & Local tumor destruction (NOS) \\
\hline 19 & Local tumor destruction or excision (NOS) \\
\hline 20 & Excision or resection of less than one lobe (NOS) \\
\hline 21 & Wedge resection \\
\hline 22 & Segmental resection (including lingulectomy) \\
\hline 23 & Excision (NOS) \\
\hline 24 & Laser excision \\
\hline 25 & Bronchial sleeve resection only \\
\hline 30 & Resection of lobe or bilobectomy, but less than whole lung \\
\hline 33 & Lobectomy with mediastinal lymph node dissection \\
\hline 45 & Lobe or bilobectomy extended (NOS) \\
\hline 46 & Lobe or bilobectomy extended with chest wall \\
\hline 55 & Pneumonectomy (NOS) \\
\hline 56 & Pneumonectomy with mediastinal lymph node dissection \\
\hline 65 & Extended pneumonectomy \\
\hline 66 & Extended pneumonectomy plus pleura or diaphragm \\
\hline 70 & Extended radical pneumonectomy \\
\hline 80 & Resection of lung (NOS) \\
\hline 90 & Surgery (NOS) \\
\hline 99 & Unknown if surgery performed \\
\hline
\end{tabular}

Table VII

CODES FOR REASON FOR NO SURGERY

\begin{tabular}{||c|l||}
\hline \hline Code & Description \\
\hline \hline 0 & Surgery performed \\
\hline 1 & Surgery not recommended \\
\hline 2 & Contraindicated due to other conditions \\
\hline 6 & Unknown reason for no surgery \\
\hline 7 & Patient or patient's guardian refused \\
\hline 8 & Recommended, unknown if done \\
\hline 9 & Unknown if surgery performed \\
\hline \hline
\end{tabular}

Table VIII

CODES FOR ORDER OF SURGERY AND RADIATION THERAPY

\begin{tabular}{||c|l||}
\hline \hline Code & Description \\
\hline \hline 0 & No radiation and/or surgery \\
\hline 2 & Radiation before surgery \\
\hline 3 & Radiation after surgery \\
\hline 4 & Radiation both before and after surgery \\
\hline 5 & Intraoperative radiation therapy \\
\hline 6 & $\begin{array}{l}\text { Intraoperative radiation with other radiation given before/after } \\
\text { surgery }\end{array}$ \\
\hline 9 & Sequence unknown, but both surgery and radiation were given \\
\hline \hline
\end{tabular}


Table IX

CODES FOR SCOPE OF REgIONAL LYMPH NODE SURGERY

\begin{tabular}{||c|l||}
\hline \hline Code & Description \\
\hline \hline 0 & No regional lymph nodes removed \\
\hline 1 & Regional lymph nodes removed (NOS) \\
\hline 2 & Intrapulmonary/ipsilateral hilar/ipsilateral peribronchial nodes \\
\hline 3 & Ipsilateral mediastinal/subcarinal nodes \\
\hline 4 & Combination of 2 and 3 \\
\hline 5 & $\begin{array}{l}\text { Contralateral mediastinal/contralateral } \\
\text { lar/ipsilateral/contralateral scalene/supraclavicular nodes }\end{array}$ \\
\hline 6 & Combination of 5 with 2 or 3 \\
\hline 9 & Unknown/not stated \\
\hline \hline
\end{tabular}

Table X

CODEs FOR CANCER STAGE

\begin{tabular}{||c|l||}
\hline \hline Code & Description \\
\hline \hline 0 & In situ (Noninvasive neoplasm) \\
\hline 1 & Localized (Invasive neoplasm confined to the lung) \\
\hline 2 & Regional (Extended neoplasm) \\
\hline 7 & Distant (Spread neoplasm) \\
\hline 9 & Unstaged/Unknown \\
\hline \hline
\end{tabular}

higher than and lower than 24.45 months.

\section{EXPERIMENTS AND RESULTS}

The distribution of survival time across all the patients is shown in Figure 1. Before performing HotSpot analysis, we would like to study the influence of each of the individual 13 attributes on survival time. For this purpose, we plotted the average survival time for different possible values of each input attribute, as shown in Figures 2-14.

We performed two independent analyses to find segments in which average survival time was higher and lower than overall average survival. Several combinations of algorithm parameters (maximum branching factor, minimum improvement in target value, and minimum segment size) were tried. Here we report the results with the following parameters: maximum branching factor $=3$, minimum improvement in target value $=1 \%$, and minimum segment size $=100$.

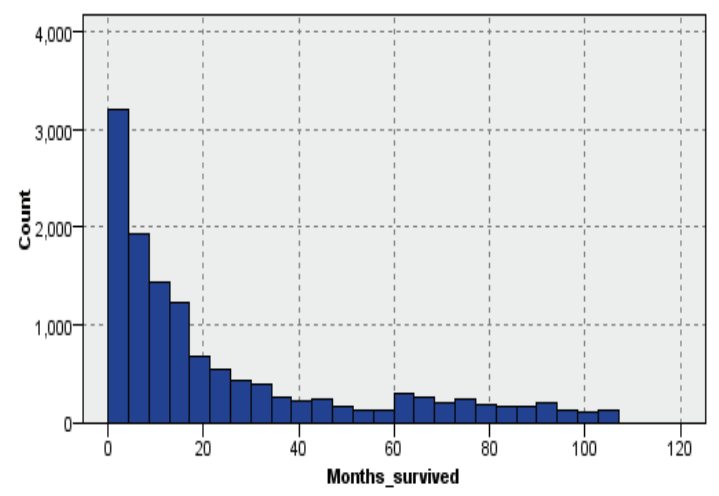

Figure 1. Distribution of survival time (in months).

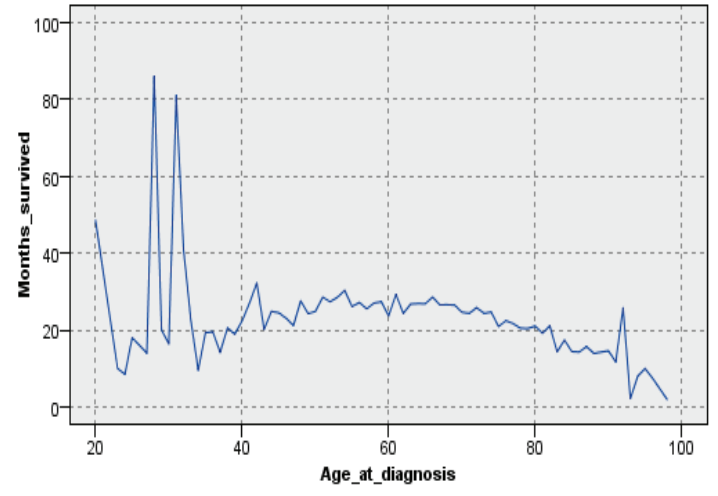

Figure 2. Survival time vs. Age at diagnosis.

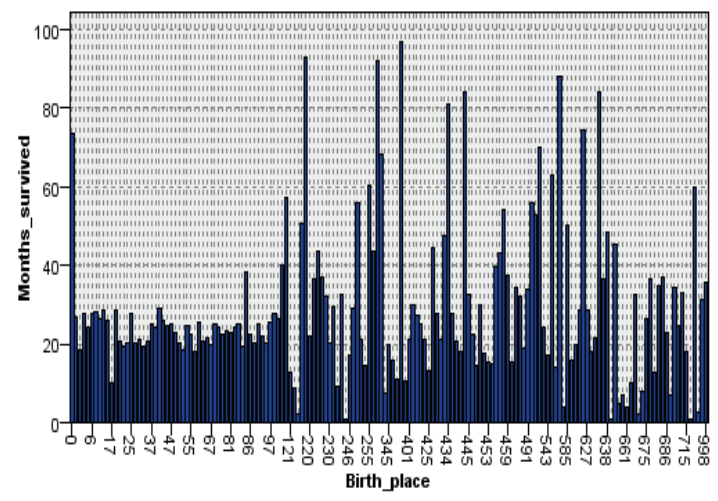

Figure 3. Survival time vs. Birth place

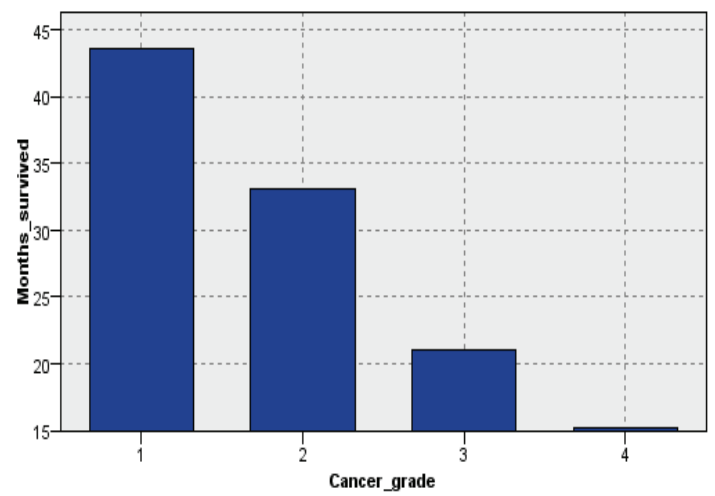

Figure 4. Survival time vs. Cancer grade. 


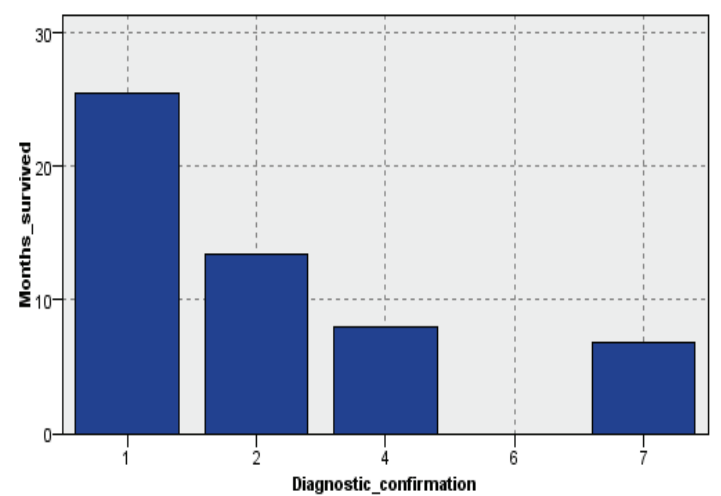

Figure 5. Survival time vs. Diagnostic confirmation.

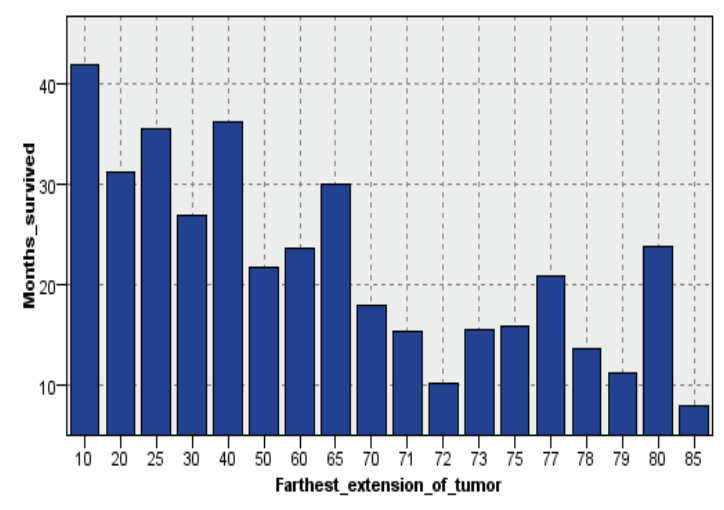

Figure 6. Survival time vs. Farthest extension of tumor.

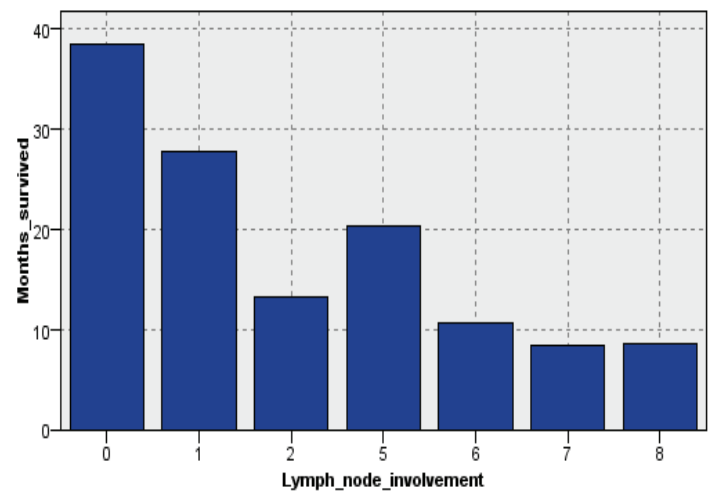

Figure 7. Survival time vs. Lymph node involvement.

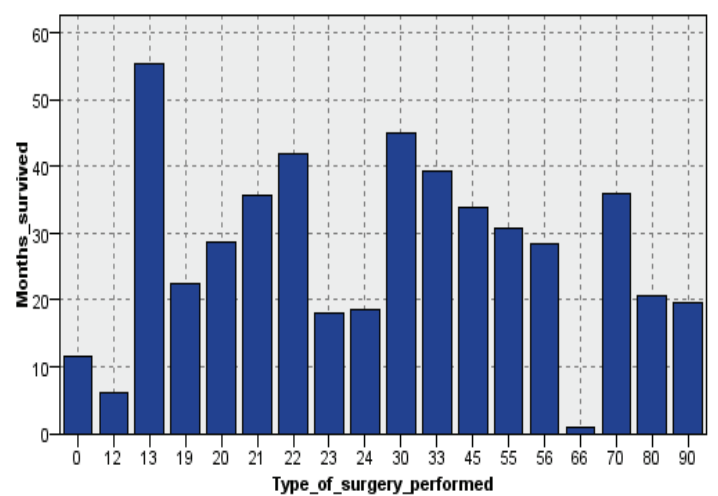

Figure 8. Survival time vs. Type of surgery performed.

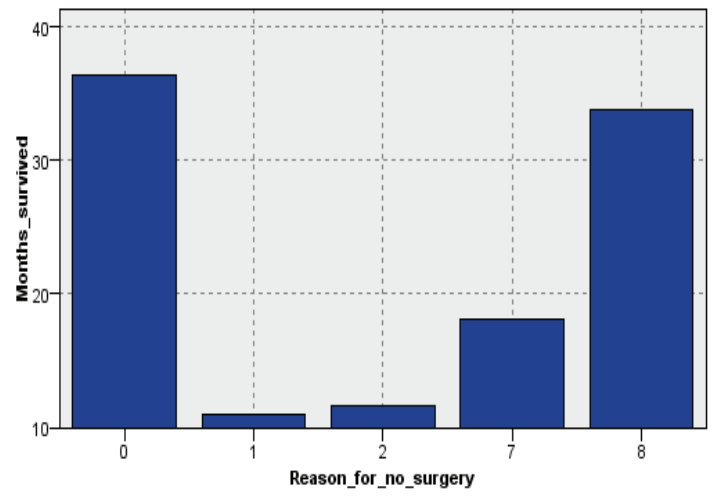

Figure 9. Survival time vs. Reason for no surgery.

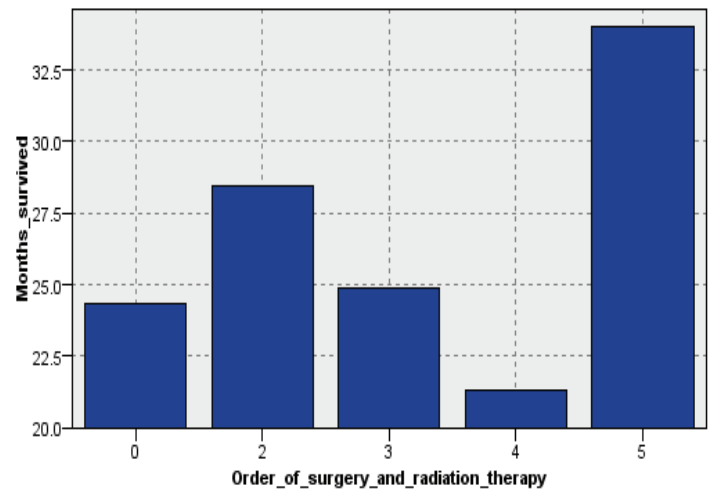

Figure 10. Survival time vs. Order of surgery and radiation therapy. 


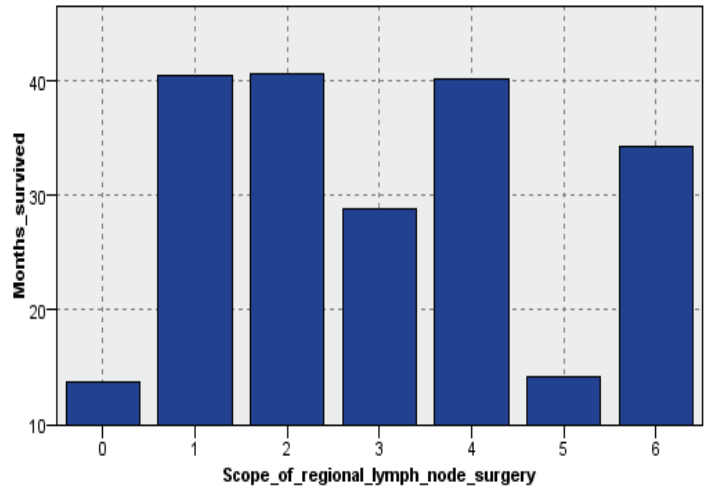

Figure 11. Survival time vs. Scope of regional lymph node surgery.

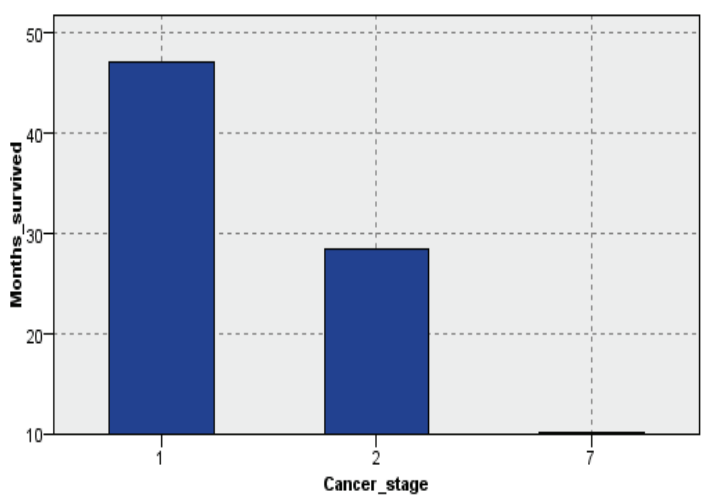

Figure 12. Survival time vs. Cancer stage.

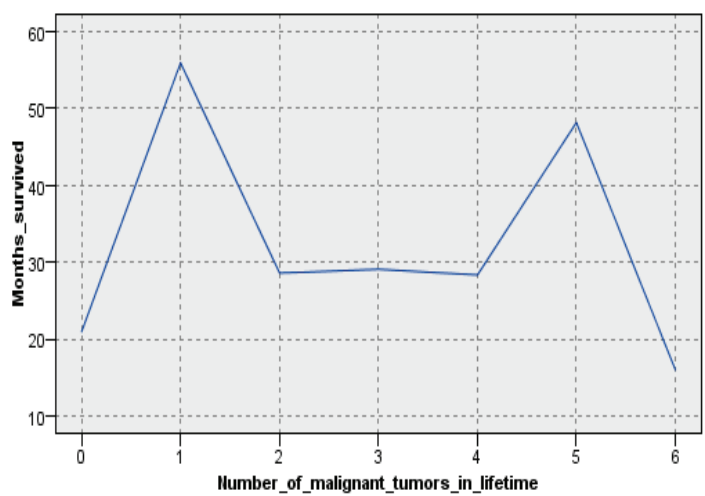

Figure 13. Survival time vs. Number of malignant tumors in the past.

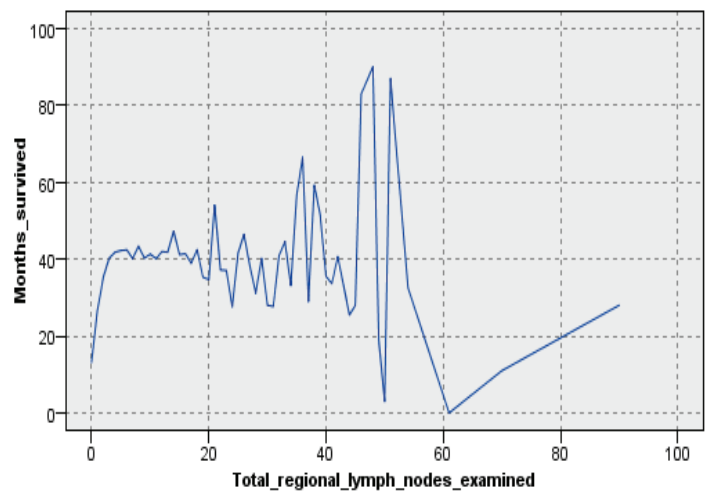

Figure 14. Survival time vs. Total regional lymph nodes examined.

Table XI

NUMBER OF ASSOCIATION RULES

\begin{tabular}{||l|l|l|l||}
\hline \hline Mode & $\begin{array}{l}\text { Generated } \\
\text { by HotSpot } \\
\text { Algorithm }\end{array}$ & $\begin{array}{l}\text { Redundant Rule Re- } \\
\text { moval - Stage I }\end{array}$ & $\begin{array}{l}\text { Redundant Rule Re- } \\
\text { moval - Stage II }\end{array}$ \\
\hline \hline $\begin{array}{l}\text { Higher } \\
\text { target } \\
\text { value }\end{array}$ & 165 & 85 & 12 \\
\hline $\begin{array}{l}\text { Lower } \\
\text { target } \\
\text { value }\end{array}$ & 64 & 32 & 6 \\
\hline \hline
\end{tabular}

As commonly known, association rule analysis invariably leads to discovery of a large number of redundant rules, which need to be removed. We used a 2-stage semi-manual procedure to remove redundant rules:

1) Stage I: Since the HotSpot algorithm tries to go deeper into the data as long as it is able to improve the target value, the leaf nodes would have the best target value compared to all the nodes on its path. So, we discard all the rules corresponding to the non-leaf nodes, and retain only the rules corresponding to the leaf nodes. This stage does not require manual intervention.

2) Stage II: Even after Stage I, there still remain quite a few redundant rules, the removal of which require domain expertise. The redundant rules at this stage were manually removed.

Table XI present the number of rules generated by the HotSpot algorithm, and the rules after each stage of redundant rule removal.

Lift of a rule is the relative improvement in the target (here survival time) as compared to the average value of the target across the entire dataset. Therefore, lift for the two modes can be defined as follows:

Lift $_{\text {higher }}=$ Avg.SurvivalTimeWithinSegment $/ 24.45$ Lift $_{\text {lower }}=24.45 /$ Avg.SurvivalTimeWithinSegment 
Table XII

NON-REDUNDANT ASSOCIATION RULES DENOTING SEGMENTS WHERE AVERAGE SURVIVAL TIME IS SIGNIFICANTLY HIGHER THAN 24.45 MONTHS

\begin{tabular}{|c|c|c|c|c|}
\hline Non-redundant rules & $\begin{array}{l}\text { Avg. Survival } \\
\text { time }\end{array}$ & Segment size & Lift & Segment description \\
\hline $\begin{array}{l}\text { Cancer stage }=1 \text {, Cancer grade }=1 \text {, Total regional } \\
\text { lymph nodes examined }>3 \text {, Order of surgery and } \\
\text { radiation therapy }=0 \text {, Type of surgery performed } \\
=30 \text {, Age at diagnosis }<=78 \text {, Number of ma- } \\
\text { lignant tumors in lifetime }<=2 \text {, Total regional } \\
\text { lymph nodes examined }<=17\end{array}$ & 68.18 & 100 & 2.788559462 & $\begin{array}{l}\text { The tumor is well-differentiated and localized, regional } \\
\text { lymph nodes examined is between } 4 \text { and } 17 \text {, age of the } \\
\text { patient at time of diagnosis is less than } 79 \text {, current tu- } \\
\text { mor is patient's first or second tumor, and resection of } \\
\text { lobe/bilobectomy is performed by the surgeon. }\end{array}$ \\
\hline $\begin{array}{l}\text { Cancer stage }=1 \text {, Age at diagnosis }<=52 \text {, Type } \\
\text { of surgery performed }=30 \text {, Total regional lymph } \\
\text { nodes examined }<=14 \text {, Total regional lymph } \\
\text { nodes examined }>0 \text {, Age at diagnosis }>38\end{array}$ & 68.11 & 100 & 2.785696465 & $\begin{array}{l}\text { The tumor is localized, age of patient is between } 39 \text { and } 52 \text {, } \\
\text { number of regional lymph nodes examined is between } 1 \text { and } \\
14 \text {, and resection of lobe/bilobectomy is performed by the } \\
\text { surgeon. }\end{array}$ \\
\hline $\begin{array}{l}\text { Type of surgery performed }=30, \text { Cancer grade }= \\
1, \text { Scope of regional lymph node surgery }=1 \text {, Total } \\
\text { regional lymph nodes examined }<=14\end{array}$ & 66.8317 & 101 & 2.733414043 & $\begin{array}{l}\text { Tumor is well-differentiated, number of regional } \\
\text { lymph nodes examined is less than } 15 \text {, resection of } \\
\text { lobe/bilobectomy is performed, and regional lymph nodes } \\
\text { are removed. }\end{array}$ \\
\hline $\begin{array}{l}\text { Cancer stage }=1, \text { Age at diagnosis }<=52 \text {, Type } \\
\text { of surgery performed }=30 \text {, Farthest extension of } \\
\text { tumor }=10 \text {, Age at diagnosis }>40\end{array}$ & 66.2613 & 111 & 2.710084704 & $\begin{array}{l}\text { Tumor is localized, age of patient is between } 41 \text { and } \\
52 \text {, tumor is confined to one lung, and resection of } \\
\text { lobe/bilobectomy is performed. }\end{array}$ \\
\hline $\begin{array}{l}\text { Type of surgery performed }=30, \text { Birth place }=99, \\
\text { Lymph node involvement }=0 \text {, Age at diagnosis } \\
<=75\end{array}$ & 64.9811 & 106 & 2.657724571 & $\begin{array}{l}\text { Patient was born in Hawaii, patient's age is less than } \\
76 \text {, there is no lymph node involvement, and resection of } \\
\text { lobe/bilobectomy is performed. }\end{array}$ \\
\hline $\begin{array}{l}\text { Cancer stage }=1, \text { Birth place }=99, \text { Reason for no } \\
\text { surgery }=0, \text { Age at diagnosis }<=82\end{array}$ & 63.9604 & 101 & 2.615977979 & $\begin{array}{l}\text { Tumor is localized, patient was born in Hawaii, patient's age } \\
\text { is less than } 83 \text {, and surgery was performed. }\end{array}$ \\
\hline $\begin{array}{l}\text { Cancer grade }=1 \text {, Total regional lymph nodes } \\
\text { examined }>6, \text { Lymph node involvement }=0 \text {, Age } \\
\text { at diagnosis }<=80 \text {, Total regional lymph nodes } \\
\text { examined }<=18\end{array}$ & 63.8614 & 101 & 2.611928883 & $\begin{array}{l}\text { Tumor is well-diffentiated, number of lymph nodes ex- } \\
\text { amined is between } 7 \text { and } 18 \text {, there is no lymph node } \\
\text { involvement, and patient's age is less than } 81 \text {. }\end{array}$ \\
\hline $\begin{array}{l}\text { Type of surgery performed }=30, \text { Cancer stage }= \\
1 \text {, Birth place }=7, \text { Farthest extension of tumor }= \\
10, \text { Total regional lymph nodes examined }>2\end{array}$ & 63.0971 & 103 & 2.580669042 & $\begin{array}{l}\text { Tumor is localized, patient was born in Connecticut, tumor } \\
\text { is confined to one lung, number of lymph nodes examined } \\
\text { is greater than 2, and resection of lobe/bilobectomy is } \\
\text { performed. }\end{array}$ \\
\hline $\begin{array}{l}\text { Cancer grade }=1, \text { Scope of regional lymph node } \\
\text { surgery }=2, \text { Lymph node involvement }=0 \text {, Age } \\
\text { at diagnosis }<=75\end{array}$ & 62.16 & 100 & 2.542341686 & $\begin{array}{l}\text { Tumor is well-differentiated, there is no lymph node in- } \\
\text { volvement, patient's age is less than } 76 \text {, and intrapul- } \\
\text { monary/ipsilateral hilar/ipsilateral peribronchial nodes are } \\
\text { removed. }\end{array}$ \\
\hline $\begin{array}{l}\text { Cancer stage }=1, \text { Birth place }=99, \text { Farthest } \\
\text { extension of tumor }=10 \text {, Age at diagnosis }<= \\
81\end{array}$ & 60.3762 & 101 & 2.469384333 & $\begin{array}{l}\text { Tumor is localized (confined to one lung), patient is born in } \\
\text { Hawaii and is less than } 82 \text { years old. }\end{array}$ \\
\hline $\begin{array}{l}\text { Cancer stage }=1 \text {, Birth place }=99 \text {, Farthest } \\
\text { extension of tumor }=10 \text {, Diagnostic confirmation } \\
=1\end{array}$ & 60.1845 & 103 & 2.46154381 & $\begin{array}{l}\text { Tumor is localized (confined to one lung), patient is born in } \\
\text { Hawaii, and cancer was confirmed by positive histology. }\end{array}$ \\
\hline $\begin{array}{l}\text { Type of surgery performed }=30, \text { Cancer stage }= \\
1, \text { Birth place }=97\end{array}$ & 58.71 & 100 & 2.401236815 & $\begin{array}{l}\text { Tumor is localized, patient is born in California, and resec- } \\
\text { tion of lobe/bilobectomy is performed by the surgeon. }\end{array}$ \\
\hline
\end{tabular}

Tables XII and XIII present the non-redundant association rules obtained with 'higher' and 'lower' mode respectively. The description of the segment features is also included in the tables.

Most of the rules obtained in both cases conform with existing biomedical knowledge and provide interesting insights into lung cancer survival.

\section{CONCLUSION AND Future WORK}

In this paper, we performed association rule mining analysis on lung cancer data from SEER to identify hotspots in the cancer data, where the patient survival time is significantly higher than and lower than the average survival time across the entire dataset.

We believe that such analysis can be very useful to identify the factors affecting survival, and aid doctors and patients in avoiding the conditions which are known to reduce survival time, and encourage the conditions which are known to increase the survival time, whenever possible. It can also aid doctors in decision making and improve informed patient consent by providing a better understanding of the risks involved in a particular treatment procedure.

Similar analysis can also be done for other cancers.

\section{ACKNOWLEDGMENT}

We thank the SEER program to make their limited-use data available for this work. This work is supported in part by NSF award numbers CCF-0621443, OCI-0724599, CCF0833131, CNS-0830927, IIS-0905205, OCI-0956311, CCF0938000, CCF-1043085, CCF-1029166, and OCI-1144061, and in part by DOE grants DE-FC02-07ER25808, DEFG02-08ER25848, DE-SC0001283, DE-SC0005309, and DE-SC0005340.

\section{REFERENCES}

[1] "Introduction to lung cancer," national Cancer Institute, SEER training modules, URL: http://raining.seer.cancer.gov/lung/intro/ accessed:

Aug 2, 2011. 
Table XIII

NON-REDUNDANT ASSOCIATION RULES DENOTING SEGMENTS WHERE AVERAGE SURVIVAL TIME IS SIGNIFICANTLY LOWER THAN 24.45 MONTHS

\begin{tabular}{|c|c|c|c|c|}
\hline Non-redundant rules & $\begin{array}{l}\text { Avg. Survival } \\
\text { time }\end{array}$ & Segment size & $\overline{\text { Lift }}$ & Segment description \\
\hline $\begin{array}{l}\text { Farthest extension of tumor }=85 \text {, Lymph node } \\
\text { involvement }=7 \text {, Order of surgery and radiation } \\
\text { therapy }=0, \text { Scope of regional lymph node surgery } \\
=0 \text {, Cancer grade }=3\end{array}$ & 5.21 & 100 & 4.692879079 & $\begin{array}{l}\text { Tumor has metastasized and is poorly differentiated, lymph } \\
\text { nodes are involved in metastasis, and no lymph nodes are } \\
\text { removed. }\end{array}$ \\
\hline $\begin{array}{l}\text { Farthest extension of tumor }=85, \text { Birth place }= \\
99, \text { Order of surgery and radiation therapy }=0, \\
\text { Type of surgery performed }=0 \text {, Cancer grade }=3\end{array}$ & 5.6727 & 110 & 4.310099247 & $\begin{array}{l}\text { Tumor has metastasized and is poorly differentiated, no } \\
\text { surgery was performed, and the patient was born in Hawaii. }\end{array}$ \\
\hline $\begin{array}{l}\text { Farthest extension of tumor }=85 \text {, Birth place }=99, \\
\text { Order of surgery and radiation therapy }=0 \text {, Type } \\
\text { of surgery performed }=0 \text {, Diagnostic confirmation } \\
=1\end{array}$ & 5.7344 & 128 & 4.263724191 & $\begin{array}{l}\text { Tumor has metastasized, no surgery was performed, cancer } \\
\text { was confirmed by positive histology, and patient was born } \\
\text { in Hawaii. }\end{array}$ \\
\hline $\begin{array}{l}\text { Farthest extension of tumor }=85, \text { Reason for no } \\
\text { surgery }=2 \text {, Diagnostic confirmation }=1\end{array}$ & 5.7803 & 132 & 4.229866962 & $\begin{array}{l}\text { Tumor has metastasized, surgery was contraindicated and } \\
\text { not performed, and cancer was confirmed by positive histol- } \\
\text { ogy. }\end{array}$ \\
\hline $\begin{array}{l}\text { Farthest extension of tumor }=72 \text {, Cancer grade }= \\
3 \text {, Type of surgery performed }=0 \text {, Lymph node } \\
\text { involvement }=2 \text {, Order of surgery and radiation } \\
\text { therapy }=0\end{array}$ & 7.5268 & 205 & 3.248379125 & $\begin{array}{l}\text { Pleural effusion has taken place, tumor is poorly differ- } \\
\text { entiated, subcarinal/carinal/mediastinal/tracheal/aortic/ pul- } \\
\text { monary ligament/pericardial lymph nodes are involved, and } \\
\text { no surgery was performed. }\end{array}$ \\
\hline $\begin{array}{l}\text { Farthest extension of tumor }=72 \text {, Diagnostic con- } \\
\text { firmation }=2 \text {, Reason for no surgery }=1\end{array}$ & 8.5982 & 112 & 2.843606801 & $\begin{array}{l}\text { Pleural effusion has taken place, cancer was confirmed by } \\
\text { positive cytology, surgery was not recommended and hence } \\
\text { not performed. }\end{array}$ \\
\hline
\end{tabular}

[2] "Lung cancer statistics," centers for 2009.

Disease Control and Prevention, URL: http://www.cdc.gov/cancer/lung/statistics/ accessed: Aug 2, 2011.

[3] L. A. G. Ries and M. P. Eisner, Cancer of the lung. National Cancer Institute, SEER Program, 2007, ch. 9.

[4] "Surveillance, epidemiology, and end results (seer) program (www.seer.cancer.gov) limited-use data (19732006)," National Cancer Institute, DCCPS, Surveillance Research Program, Cancer Statistics Branch, 2008, released April 2009, based on the November 2008 submission.

[5] "Overview of the seer program," surveillance Epidemiology and End Results, URL: http://seer.cancer.gov/about/ accessed: Aug 2, 2011.

[6] L. A. Gloeckler Ries, M. E. Reichman, D. R. Lewis, B. F. Hankey, and B. K. Edwards, "Cancer Survival and Incidence from the Surveillance, Epidemiology, and End Results (SEER) Program," Oncologist, vol. 8, no. 6, pp. 541-552.

[7] A. Agrawal, S. Misra, R. Narayanan, L. Polepeddi, and A. Choudhary, "A lung cancer outcome calculator using ensemble data mining on seer data," in Proceedings of the Tenth International Workshop on Data Mining in Bioinformatics, ser. BIOKDD '11, 2011, pp. 5:1-5:9.

[8] R. Agrawal, T. Imieliński, and A. Swami, "Mining association rules between sets of items in large databases," in Proceedings of the 1993 ACM SIGMOD international conference on Management of data, ser. SIGMOD '93, 1993.

[9] M. Hall, E. Frank, G. Holmes, B. Pfahringer, P. Reutemann, and I. H. Witten, "The weka data mining software: An update," SIGKDD Explorations, vol. 11, no. 1, 